Economics Development Analysis Journal 6 (3) (2017)

\title{
Evaluasi dan Analisis Dampak Program Corporate Social Responsibility Badak LNG
}

\author{
Hanes Utama ${ }^{1 凶}$, Busori Sunaryo ${ }^{2}$ \\ PT Badak NGL, Bontang
}

\section{Info Artikel \\ Abstrak}

Sejarah Artikel:

Diterima April 2017

Disetujui Juni 2017

Dipublikasikan Agustus 2017

Keywords:

Evaluation, Society, Impact, Satisfaction

\begin{abstract}
Tujuan penelitian ini adalah untuk mengevaluasi kegiatan CSR Badak LNG dengan mengukur tingkat kepuasan masyarakat terhadap program CSR yang telah dijalankan;. Adapun metode yang digunakan adalah melalui pendekatan kajian input, output dan impact melalui analisis Indeks Kepuasan Masyarakat, Importence Performance Analysis, dan Compass Sustainability Analysis. Hasil penelitian menunjukkan secara keseluruhan kepuasan masyarakat terhadap pelayanan program CSR Badak LNG menunjukkan parameter sangat baik. Tingkat kesesuaian antara kepuasan kinerja dengan tingkat kepentingan masyarakat masuk dalam kategori sangat baik. Indikator kejelasan petugas pendamping, tanggung jawab petugas pendamping, kemampuan petugas pendamping, kesopanan petugas pendamping, dan kepastian biaya pelayanan adalah indikator yang memiliki harapan tinggi dari masyarakat penerima manfaat, dan perusahaan memiliki kinerja yang sangat baik dalam hal tersebut. Dampak positif yang diterima dari kegiatan CSR pada dimensi nature, wellbeing, economy, social di Kota Bontang sangat tinggi, di antaranya terjadinya peningkatan kualitas lingkungan, pemanfaatan potensi alam, peningkatan pendapatan masyarakat, pengentasan kemiskinan, peningkatan kemandirian UMKM, tereksposenya kebudayaan masyarakat, dan tingginya tingkat kepuasan masyarakat terhadap kegiatan-kegiatan CSR Badak LNG.
\end{abstract}

\begin{abstract}
The purpose of this study is to evaluate the CSR activities of LNG Agency by measuring the level of community satisfaction on the CSRprogram that has been run. It has an impact to the improvement quality program and increase peoples participation as a CSR awardee. The research methods are, input outout and impact study by peoples satisfactory index, Importance performance analysis, and compass sustainability analysis. The research result shows that the peoples satisfaction towards CSR program are in the very good category. The appropriate between satisfaction performance and people urgency also in a very good category. The performance, responsibility, ability, kindness, and the certain of services cost of assistant officer belongs to high prospect indicator from the society. Therefore, company has a very good performance in that program. The positive impact of CSR programs in the nature, well-being, economy, social in Bontang city are very high. There is an improvement of environment quality, the utilization of nature potential, the increase of people income, poverty reduction, SME's tenacity improvement, cultural advertisement, and people satisfaction are in the high level towards CSR programs of Badak LNG.
\end{abstract}

\footnotetext{
${ }^{凶}$ Alamat korespondensi:

Satimpo, Bontang, Kalimantan Timur
}

ISSN 2252-6965

E-mail: hanes@badaklng.co.id 


\section{PENDAHULUAN}

Pembangunan adalah serangkaian proses perubahan yang komprehensif, berkelanjutan, dan multidimensional. Saat ini pembangunan tidak hanya menjadi tanggung jawab pemerintah saja, melainkan juga menjadi tanggung jawab sektor swasta dan masyarakat. Perusahaan yang semula hanya berpikir kepentingan ekonomisnya saja, sekarang juga harus memiliki tanggung jawab pada masyarakat dan mendorong upaya percepatan pembangunan.

Bentuk tanggung jawab perusahaan yang kita kenal dengan Corporate Social Responsibility (CSR) adalah suatu bentuk komitmen perusahaan untuk bertindak secara etis terhadap pemangku kepentingan secara langsung maupun tidak langsung dengan meningkatkan ualitas hidup dan kesejahteraan dengan mempertimbangkan aspek sosial, ekonomi, dan lingkungan dari aktivitas perusahaan (The World Business Council for Sustainable Development, 2005; Inter-national Organization for Standardization, 2007). Tanggung Jawab Sosial Perusahaan adalah konsep manajemen bisnis, yang menurutnya perusahaan tidak hanya berorientasi pada keuntungan tetapi juga memperhitungkan kepentingan sosial dan ekologis (Kadlubek, 2015).

Ada hubungan yang sangat erat antara CSR dengan pembangunan berkelanjutan (sustainability development). Suatu perusahaan yang ingin menerapkan konsep pembangunan berkelanjutan harus memperhatikan Triple $P$ yaitu profit, planet, dan people. Tiga $\mathrm{P}$ tersebut merupakan wujud dari aspek ekonomi, aspek lingkungan, dan aspek sosial. Triple Bottom Line meliputi kesejahteraan atau kemakmuran ekonomi (economic prosperity), peningkatan kualitas lingkungan (environmental quality), dan keadilan sosial (social justice). Triple Bottom Line terdiri dari aspek keuangan, aspek sosial, dan aspek lingkungan perusahaan.

Pemerintah secara tegas memberi porsi kepada perusahaan untuk turut mendukung pembangunan yang ada di Indonesia dengan mengeluarkan beberapa peraturan pemerintah tentang kepedulian lingkungan, tak terkecuali dalam bidang migas. Dalam Peraturan Pemerintah RI No.35 Tahun 2004 tentang kegiatan usaha hulu minyak dan gas bumi pada bab VIII tentang keselamatan dan kesehatan kerja serta pengelolaan lingkungan hidup serta pengembangan masyarakat setempat. Tertuang pada pasal 74 pasal (1) yaitu kontraktor dalam melaksanakan kegiatannya ikut bertanggung jawab dalam mengembangkan Iingkungan dan masyarakat setempat, dan pasal (2) tanggung jawab kontraktor dalam mengembangkan lingkungan dan masyarakat setempat sebagaimana dimaksud dalam ayat (1), adalah keikutsertaan dalam mengembangkan dan memanfaatkan potensi kemampuan masyarakat setempat antara lain dengan cara mempekerjakan tenaga kerja dalam jumlah dan kualitas tertentu sesuai dengan kompetensi yang dibutuhkan, serta meningkatkan lingkungan, hunian masyarakat agar tercipta keharmonisan antara kontraktor dengan masyarakat di sekitarnya.

Badak LNG sebagai perusahaan, telah menjalankan program - program Corporate Social Responsibility (CSR) yang diharapkan dapat memberikan stimulus positif bagi perkembangan ekonomi wilayah disekitar perusahaan maupun pada kelompok sasaran. Melalui tanggung jawab sosial perusahaan atau Corporate Social Responsibility (CSR), perusahaan menjadi agen perubahan yang tidak hanya berorientasi pada profit, tetapi juga tanggung jawab moral dan sosial memberikan keuntungan kepada seluruh stakeholder di antaranya masyarakat dan kelompok-kelompok sasaran yang berpotensi menerima dampak dari aktivitas perusahaan serta mendukung Pemerintah mempercepat proses pembangunan. perusahaan dari wilayah modal sosial yang tinggi menunjukkan CSR yang lebih tinggi. Hasil ini menunjukkan bahwa kepentingan pribadi pemegang saham atau manajer tidak menjelaskan semua CSR perusahaan, namun kecenderungan altruistik dari kawasan ini mungkin juga berperan (Jha \& James, 2015)

Melihat geografi Kota Bontang menunjukkan $70 \%$ dari geografi Kota Bontang 
merupakan laut, dengan demikian aktivitas sosial dan ekonomi masyarakat kota Bontang berada di kawasan pesisir pantai. Menyadari pentingnya laut bagi masyarakat Kota Bontang, Badak LNG melakukan pemberdayaan kepada masyarakat pesisir melalui sejumlah program pelatihan dan pendampingan khususnya pada kelompok nelayan budidaya ikan kerapu, kelompok tani mangrove, pengembangan kawasan wisata pesisir, dan laut. Selain itu juga Badak LNG memberikan berbagai pemberdayaan, pembinaan serta pendanaan bagi kelompok-kelompok di luar dari pesisir, diantaranya budidaya jamur, kelompok ternak mandiri, kelompok pengelola sampah plastik, kelompok pembatik dan penjahit, serta beberapa kelompok lainnya.

Perusahaan yang telah berhasil dalam mengimplementasikan program CSR melalui beberapa tahap mulai dari tahap perencanaan, tahap pelaksanaan, tahap pemantauan, dan evaluasi, dan yang terakhir tahap pelaporan (Wibisono, 2007).

Indikator keberhasilan merupakan suatu hal yang sangat penting untuk setiap pelaksanaan program CSR. Hal ini dibutuhkan untuk mengetahui kinerja program yang sudah terlaksana. Dengan adanya indikator keberhasilan, perusahaan dapat melakukan evaluasi untuk menyiapkan rencana strategis selanjutnya yang dapat dilakukan untuk memperbaiki kinerja dari program sebelumnya. Dalam upaya pengembangan masyarakat, terdapat ciri-ciri atau indikator yang menunjukkan terjadinya upaya pengembangan masyarakat seperti yang diungkapkan oleh Chaskin (2001) seperti dikutip oleh Saputro (2010), yaitu: a sense of community (rasa memiliki terhadap komunitas); a level of commitment (tingkat komitmen); the ability to solve problems (kemampuan untuk memecahkan masalah); dan access to resources (akses kepada sumber daya).

Program-program CSR yang di lakukan Badak LNG ini secara berkesinambungan dievaluasi dampak sosial ekonominya sehingga kinerja dari program-program tersebut dapat terpantau, terukur, dan ditingkatkan dampak positifnya bagi masyarakat di sekitar perusahaan khususnya dan masyarakat Kota Bontang pada umumnya.

Semua tahapan tersebut, Badak LNG melibatkan masyarakat di dalam implementasi program CSR. Hal ini tentu saja berdampak pada peningkatan kualitas program serta meningkatkan peran partisipasi masyarakat sebagai kelompok sasaran penerima program CSR Badak LNG. Evaluasi dampak yang dilakukan ini untuk mengukur capaian-capaian dan dampak program CSR Badak LNG.

Sesuai uraian diatas maka pengukuran kepuasan masyarakat terhadap program CSR yang dilakukan oleh perusahaan juga harus mengacu pada unsur-unsur yang sifatnya secara sosial berlangsung dengan kontinyu (social sustainability). Ukuran social sustainability terdiri dari 3 aspek yaitu : Ekonomi, Sosial, dan Lingkungan (Asy'ari, 2009)

Supriadinata (2013) menggunakan beberapa indikator untuk menilai efektivitas suatu program CSR. Indikator penilaian tersebut antara lain adalah effectivity (manfaat), relevance (kesesuaian), sustainability (keberlanjutan), impact (dampak), dan empowerment (pemberdayaan). Pengukuran dan penerapan indikator keberhasilan menjadi penting sebagai salah satu alat untuk mengukur efektivitas keberhasilan program.

CSR diperkirakan mampu memberikan manfaat yang demikian besar, maka sudah sewajarnya kepuasan masyarakat yang menjadi sasaran program CSR harus dapat dipenuhi. Masyarakat yang seperti ini bisa dianggap sebagai konsumen yang berharga sehingga perlu diteliti bagaimana tingkat kepuasan mereka terhadap program CSR yang sudah dilaksanakan.

Penelitian ini memiliki dua tujuan utama yaitu 1) Mengevaluasi kegiatan CSR Badak LNG dengan mengukur tingkat kepuasan masyarakat terhadap program CSR yang telah dijalankan; 2) Menganalisis dampak Program CSR Badak LNG.

\section{METODE PENELITIAN}

Untuk mengevaluasi dan melihat dampak program CSR Badak LNG di lihat melalui input, 
output, dan impact. Input yang diberikan berupa dana, pendampingan dalam perencanaan, pelaksanaan dan evaluasi program. Outcome dari program CSR Badak LNG ini berupa adanya peningkatan pendapatan dan kesejahteraan masyarakat anggota kelompok mitra binaan dan dampaknya dapat dilihat dari tingkat kepuasan yang dirasakan oleh masyarakat sebagai penerima manfaat dari program CSR Badak LNG.

Penelitian ini untuk melihat evaluasi CSR Badak LNG di mana kegiatan ini di lakukan di wilayah kelompok penerima manfaat yang berada di Kota Bontang pada bulan Mei Agustus 2016

Teknik penelitian ini menggunakan purposive sampling yaitu peneliti mengambil responden sebanyak 150 orang yang berasal dari kelompok mitra binaan Badak LNG sebagai key informant.

Tabel 1. Mitra Binaan CSR Badak LNG

\begin{tabular}{lc}
\hline NamaKelompok & $\begin{array}{c}\text { Kelurahan } \\
\text { / Wilayah }\end{array}$ \\
\hline $\begin{array}{l}\text { Kelompok Tani Lestari } \\
\text { Indah }\end{array}$ & \\
Kelompok Daun Harum & \\
Kelompok Mangrove Indah & $\begin{array}{c}\text { Tanjung } \\
\text { Laut Indah }\end{array}$ \\
Kelompok Tani Alam & \\
Permai & \\
Kelompok Wanita Pesisir & \\
Kelompok Thalita & \\
Mangrove & \\
Kelompok Golden Crusty & \\
Crabs & \\
\hline Kelompok KaryaWanita & Tanjung \\
Kelompok Wanita Mandiri & Limau \\
\hline $\begin{array}{l}\text { Kelompok Saputra Snack } \\
\text { Kelompok Gotong Royong }\end{array}$ & Api-api \\
(Lele) & \\
KUBE Mekar Mandiri & \\
Kelompok Mitra Sejati & \\
Kocibu) & \\
\hline
\end{tabular}

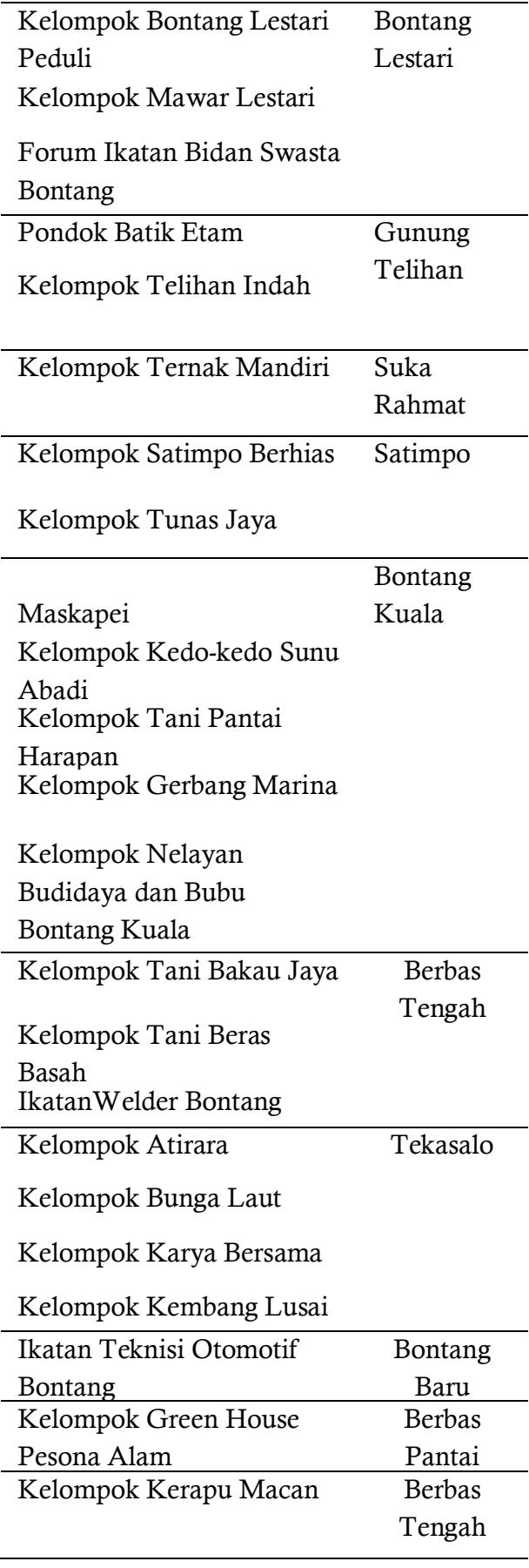

Teknik analisis yang digunakan yaitu analisis kuantitatif dan kualitatif (deskriptif). Analisis Indeks Kepuasan Masyarakat (IKM) dan Metode Importence Performance Analysis (IPA) untuk mengukur tingkat kepuasan masyarakat terhadap program CSR yang telah dijalankan. Serta analisis Compass Sustainability Analysis untuk mengevaluasi dampak program CSR Badak LNG. 
Nilai IKM dihitung dengan menggunakan nilai rata-rata tertimbang masing-masing indikator pelayanan program. Dalam perhitungan Indeks Kepuasan Masyarakat (IKM) terdapat 14 indikator pelayanan yang dikaji, setiap indikator memiliki penimbang yang sama dengan rumus berikut : (Kep.Men PAN Nomor 63/KEP/M.PAN/7/2003).

$$
\text { Nilai Penimbang }=\frac{\text { Jumlah Bobot }}{\text { Jumlah Indikator }}=1=0,071
$$

Untuk memperoleh nilai IKM unit pelayanan digunakan pendekatan nilai rata-rata tertimbang dengan rumus sebagai berikut:

$\mathrm{IKM}=\frac{\text { Total dari Nilai Persepsi Per Indikator }}{\text { Total Indikator yang Terisi }} \mathrm{x}$ Nilai Penimbang

Untuk memudahkan interpretasi terhadap nilai IKM yaitu antara 25 s.d 100 maka hasil penilaian tersebut diatas dikonversikan dengan nilai dasar 25 , dengan rumus sebagai berikut:

Tabel 2. Nilai Konversi Indeks Kepuasan Masyarakat

\begin{tabular}{|c|c|c|c|c|}
\hline $\begin{array}{l}\text { Nilai } \\
\text { Persepi }\end{array}$ & $\begin{array}{c}\text { Nilai } \\
\text { Inter } \\
\text { val } \\
\text { IKM }\end{array}$ & $\begin{array}{c}\text { Nilai } \\
\text { Interval } \\
\text { Konver } \\
\text { si IKM }\end{array}$ & $\begin{array}{c}\text { Mutu } \\
\text { Pelayaanan }\end{array}$ & $\begin{array}{c}\text { Kinerja } \\
\text { Unit } \\
\text { Pelaya } \\
\text { nan }\end{array}$ \\
\hline 1 & $\begin{array}{l}1,00- \\
<1,75\end{array}$ & $\begin{array}{c}25,00-< \\
43,75\end{array}$ & D & $\begin{array}{c}\text { Tidak } \\
\text { Baik }\end{array}$ \\
\hline 2 & $\begin{array}{l}1,75- \\
<2,50\end{array}$ & $\begin{array}{l}43,75- \\
<62,50\end{array}$ & C & $\begin{array}{c}\text { Kurang } \\
\text { Baik }\end{array}$ \\
\hline 3 & $\begin{array}{l}2,50- \\
<3,25\end{array}$ & $\begin{array}{l}62,50- \\
<81,25\end{array}$ & B & Baik \\
\hline 4 & $\begin{array}{l}3,25- \\
4,00\end{array}$ & $\begin{array}{c}81,25- \\
100\end{array}$ & A & $\begin{array}{c}\text { Sangat } \\
\text { Baik }\end{array}$ \\
\hline
\end{tabular}

Metode Importence Performance Analysis (IPA) juga digunakan untuk menganalisis kepuasan masyarakat penerima manfaat program CSR Badak LNG. Metode ini menjelaskan hubungan antara tingkat kepentingan program CSR dengan tingkat kinerja perusahaan yang menghasilkan nilai kesesuaian harapan masyarakat penerima manfaat program tersebut. Penentuan tingkat kepentingan program bantuan CSR Badak LNG dengan melakukan pembobotan yaitu dengan memberikan nilai bobot 1 s.d 4 pada setiap pertanyaan. Adapun penilaian menurut tingkat kepentingan program bantuan CSR Badak LNG dapat dilihat pada tabel 3 .

Tabel 3. Kriteria Penilaian Persepsi Masyarakat

\begin{tabular}{llc}
\hline \multirow{2}{*}{ Nilai } & \multicolumn{2}{c}{ Persepsi Masyarakat } \\
\cline { 2 - 3 } & Tingkat & Tingkat Kinerja \\
& Kepentingan & Perusahaan \\
\hline 1 & Tidak Penting & Tidak Puas \\
2 & Kurang Penting & Kurang Puas \\
3 & Penting & Puas \\
4 & Sangat Penting & Sangat Puas \\
\hline
\end{tabular}

Sama halnya dengan tingkat kepentingan, tingkat kinerja perusahaan juga diberi bobot, yang dapat kita lihat pada tabel 3. Perbandingan antara tingkat kepentingan dengan tingkat kinerja menghasilkan tingkat kesesuaian pada tingkat kepentingan di wakili oleh huruf $\mathrm{Y}$, sedangkan pada tingkat kinerja di wakili oleh huruf $\mathrm{X}$. Adapun rumus dari tingkat kesesuaian responden adalah sebagai berikut :

$$
\mathrm{Tki}=\frac{\mathrm{Xi}}{\mathrm{Yi}} \times 100 \%
$$

Keterangan:

Tki = Tingkat Kesesuaian Responden

$\mathrm{Xi}=$ Skor Penilaian Kinerja

Perusahaan

Yi $=$ Skor Penilaian Kepentingan

Masyarakat

Bobot penilaian kinerja atribut adalah nilai dari tanggapan responden terhadap indikator-indikator kinerja program bantuan CSR Badak LNG. Apabila nilai Tki $<100 \%$, maka kinerja indikator belum memenuhi kepuasan masyarakat, sebaliknya apabila nilai Tki $>100 \%$ maka indikator kinerja telah memenuhi kepuasan masyarakat. Bobot penilaian kinerja atribut pelayanan program dan 
bobot penilaian tingkat kepentingan masyarakat dibuatkan rata-rata kemudian di formulasikan ke dalam Diagram Cartesius. Secara jelas bangunan diagram cartesius dapat kita lihat pada gambar 1 .

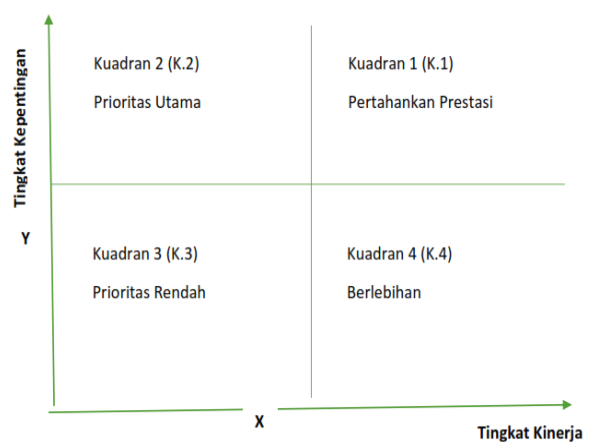

Gambar 1. Diagram Cartesius, Tingkat Kepentingan dan Kinerja

Tingkat kemandirian kelompok mitra binaan CSR Badak LNG diukur dengan menggunakan alat (tool) dan serta menggunakan analisis Compass Sustainability Analysis dengan 6 (enam) indikator kemandirian yaitu :

1. Dukungan alat produksi

2. Pengelolaan keuangan

3. Pengelolaan administrasi

4. Pengembangan keterampilan anggota kelompok

5. Pengembangan jejaring sosial (networking)

6. Kerjasama Kelompok (trust)

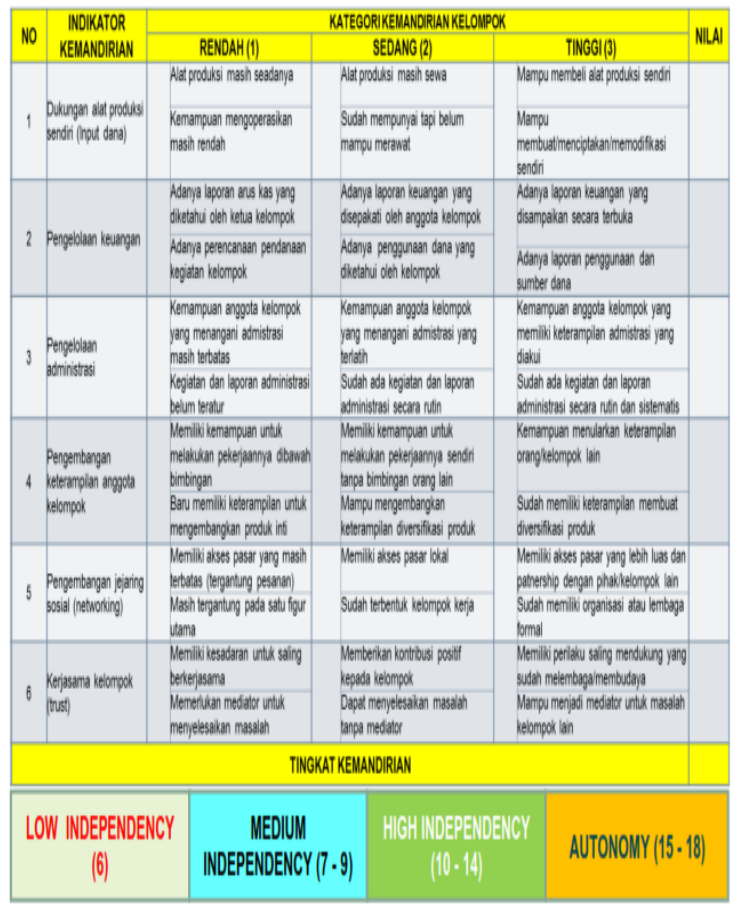

Gambar 2. Kategori dan Pembobotan Indikator Kemandirian Kelompok

\section{HASIL DAN PEMBAHASAN}

Pelayanan program bantuan CSR Badak LNG tahun 2015-2016 terdapat 2 jenis bantuan yang diberikan, yaitu bantuan dalam bentuk donasi dan capacity building. Bantuan dalam bentuk donasi yaitu bantuan yang sifatnya fisik dan kebutuhan masyarakat dalam jangka pendek, seperti bantuan infrastruktur (workshop) produksi kelompok, bantuan pemasaran dan networking, bantuan kesehatan dan lain sebagainya. Jenis program CSR Badak LNG yang telah berjalan pada tahun 2015-2016 ini terdapat 36 kelompok yang tersebar di 10 wilayah kelurahan binaan yang ada di Kota Bontang dengan berbagai jenis usaha dan produk.

Untuk mengevaluasi kegiatan CSR Badak LNG dan mengukur tingkat kepuasan masyarakat terhadap program CSR yang telah dijalankan dapat dinilai dengan mengukur Indeks Kepuasan Masyarakat (IKM). 


\begin{tabular}{|r|l|c|}
\hline No & \multicolumn{1}{|c|}{ Unit Pelayanan } & Nilai Unsur Pelayanan \\
\hline 1 & Prosedur Pelayanan & 3,01 \\
\hline 2 & Persyartan pelayanan & 3,07 \\
\hline 3 & Kejelasan Petugas / Pendamping & 3,24 \\
\hline 4 & Kedisiplinan Petugas / Pendamping & 3,08 \\
\hline 5 & Tanggungajawan Petugas / Pendamping & 3,35 \\
\hline 6 & Kemampunan Petugas / Pendamping dalam & 3,32 \\
\hline 7 & Pelayanan & Kecepatan Pelayanan \\
\hline 8 & Keadilan Mendapatkan Pelayanan & 3,26 \\
\hline 9 & Kesopanan \& keramahan Petugas / Pendamping & 3,01 \\
\hline 10 & Kewajaran Biaya Pelayanan & 3,5 \\
\hline 11 & Kepastian Biaya Pelayanan & 3,66 \\
\hline 12 & Kepastian Jadwal Pelayanan & 3,32 \\
\hline 13 & Kenyamanan Lingkungan & 3,12 \\
\hline 14 & Keamanan Lingkungan & 3,52 \\
\hline & Nilai Indeks & 3,58 \\
\hline
\end{tabular}

Gambar 3. Nilai Rata-rata Per Unsur Pelayanan Program CSR Badak LNG Tahun 2015-2016 Sumber: data primer, diolah

Pada program CSR Badak LNG tahun 2015-2016 ini dihitung dengan menggunakan nilai rata - rata tertimbang masing - masing indikator pelayanan program. Dalam perhitungan Indeks Kepuasan Masyarakat terdapat 14 indikator unsur pelayanan yang di kaji, setiap unsur pelayanan memiliki penimbang yang sama. Nilai rata - rata per unsur pelayanan program CSR Badak LNG dapat kita lihat pada gambar 2 .

Berdasarkan nilai per unsur pelayanan di atas, maka nilai kepuasan di peroleh dengan cara mengalikan masing - masing nilai rata- rata unsur pelayanan dengan bobot nilai rata- rata tertimbang (NRR x 0,071), sehingga di peroleh nilai kepuasan sebesar 3,27. Dengan demikian nilai kepuasan unit pelayanan hasilnya dapat disimpulkan pada gambar 3 .
Tabel 4. Nilai Kepuasan Unit Pelayanan

\begin{tabular}{cccc}
\hline Nilai & IKM Unit & $\begin{array}{c}\text { Mutu } \\
\text { IKM }\end{array}$ & $\begin{array}{c}\text { Kinerja } \\
\text { Pelayanan }\end{array}$ \\
\hline 3,27 & 81,63 & A & $\begin{array}{c}\text { Sayangat } \\
\text { Baik }\end{array}$ \\
\hline
\end{tabular}

Berdasarkan perhitungan di atas, secara keseluruhan indeks kepuasan masyarakat terhadap pelayanan program bantuan CSR Badak LNG dalam parameter sangat baik.

Pengukuran tingkat kepuasan masyarakat terhadap program CSR juga dapat dilihat dari Importance Performance Analysis (IPA) yang digunakan untuk menganalisis tingkat kepentingan dan kinerja CSR Badak LNG. IPA dalam evaluasi ini menganalisis tentang persepsi masyarakat terhadap tingkat kepentingan dan kinerja program CSR Badak LNG, lalu menentukan tingkat kesesuaian antara tingkat kepentingan dengan tingkat kinerja CSR Badak LNG serta menganalisis diagram Cartesius berdasarkan kuadran - kuadran di dalam diagram tersebut.

Penilaian Masyarakat terhadap Tingkat Kinerja dan Kepentingan pada IndikatorIndikator Kualitas Pelayanan Program CSR Badak LNG. Penilaian masyarakat penerima manfaat terhadap tingkat kinerja dan tingkat kepentingan terhadap 14 indikator pelayanan program CSR Badak LNG adalah sebagai berikut :

\section{Prosedur Pelayanan}

Indikator prosedur pelayanan terdiri dari tiga sub indikator yaitu tingkat keterbukaan informasi mengenai prosedur pelayanan pemberian bantuan, tingkat kejelasan alur pengajuan program serta tingkat kesederhanaan prosedur pelayanan. 


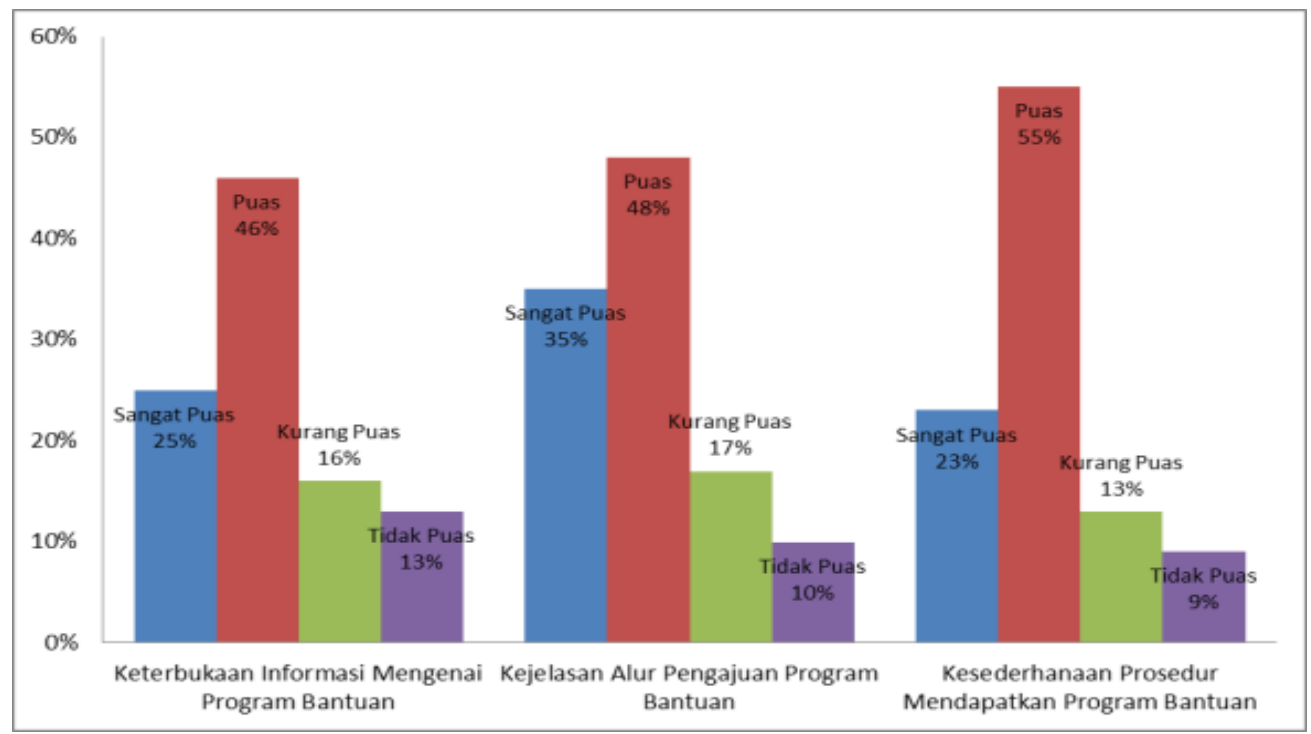

Gambar 4. Tingkat Kinerja Perusahaan pada Indikator Prosedur Pelayanan

Sumber: data primer, diolah

Berdasarkan gambar 4 sebagian besar responden penerima manfaat menyatakan tingkat kinerja yang PUAS, hal ini terjadi karena adanya informasi prosedur yang jelas diketahui oleh masyarakat serta kesederhanaan prosedur dalam mengajukan permohonan bantuan CSR Badak LNG. Berdasarkan jumlah bobot rata-rata ketiga sub indikator tersebut, maka nilai rata - rata (NRR) untuk indikator prosedur pelayanan program CSR Badak LNG adalah sebesar 3,01, dengan demikian dapat dikategorikan dalam kondisi Baik.

Badak LNG mempunyai nilai rata-rata 3,46, Bila dibandingkan dengan nilai tingkat kinerja nilai tingkat kinerja yang dirasakan oleh masyarakat yaitu 3,01, maka didapat nilai Badak LNG kesesuaian antara kinerja perusahaan dengan kepentingan masyarakat sebesar $87 \%$ yang artinya kepentingan atau harapan masyrakat terpenuhi sebesar $87 \%$.

\section{Persyaratan Pelayanan}

Indikator persyaratan pelayanan terdiri dari dua sub indikator, yaitu kemudahan dalam mengurus dan memenuhi persyaratan
Dengan melihat gambar 2, tingkat kepentingan masyarakat terhadap indikator prosedur pelayanan cukup tinggi ini menginginkan adanya kejelasan informasi dan prosedur pelayanan yang terbuka guna memperoleh program bantuan CSR Badak LNG. Prosedur yang jelas dan mudah dimengerti merupakan langkah awal agar masyarakat menjadikan program CSR Badak LNG sebagai salah satu kekuatan dalam meningkatkan kesejahteraan masyarakat. Secara keseluruhan nilai tingkat kepentingan pada indikator Prosedur Pelayanan program CSR mendapatkan program bantuan serta indikator kejelasan mengenai persyaratan pengajuan program bantuan. Dari kedua sub indikator tersebut diatas menghasilkan nilai rata-rata sebesar 3,07 sehingga secara keseluruhan indikator persyaratan pelayanan dalam kondisi yang BAIK. Persyaratan untuk mendapatkan pelayanan program CSR Badak LNG menjadi sangat penting mengingat masyarakat di sekitar wilayah cakupan program perusahaan harus memenuhi persyaratan tersebut untuk mendapat pelayanan dari program CSR Badak LNG. 


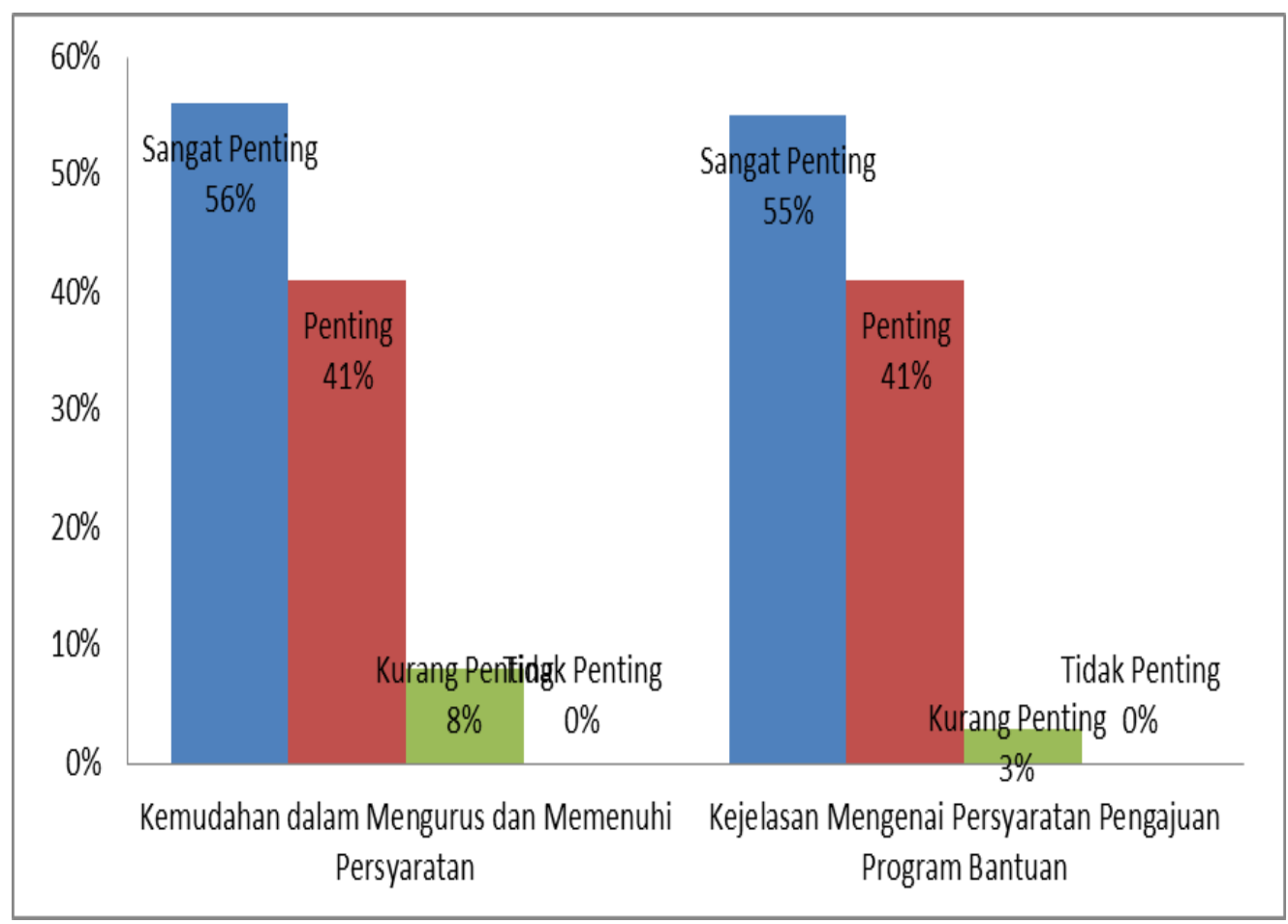

Gambar 5. Tingkat Kepentingan Masyarakat pada Indikator Prosedur Pelayanan

Hasil nilai tingkat kepentingan masyarakat pada indikator persyaratan pelayanan masyarakat penerima manfaat program secara keseluruhan (lebih dari $50 \%$ ) menyatakan bahwa kemudahan dan kejelasan persyaratan pelayanan adalah penting dan lebih $40 \%$ menyatakan sangat penting.

Secara keseluruhan berdasarkan gambar 3 nilai rata-rata tingkat kepentingan pada indikator persyaratan pelayanan adalah 3,52 yang artinya responden menganggap sangat penting akan kemudahan dan kejelasan mengenai persyaratan pelayanan. Sementara itu tingkat kesesuaian antara nilai kinerja dan nilai kepentingan pada indikator persyaratan pelayanan di peroleh tingkat kesesuaian sebesar $87 \%$ yang artinya kepentingan masyarakat terpenuhi sebesar $87 \%$.

\section{Kejelasan Petugas / Pendamping}

Indikator kejelasan petugas / pendamping pelayanan ini yaitu tingkat kepastian mengenai Identitas petugas pendamping pelayanan program CSR Badak
LNG di masyarakat. Kepastian identitas dan petugas pendamping ini maksudnya yaitu masyarakat penerima manfaat dapat mengenal secara pasti adanya petugas pendamping dalam program CSR Badak LNG.

Berdasarkan gambar 4, terlihat bahwa 93 $\%$ masyarakat penerima manfaat menyatakan PUAS dan mengetahui secara pasti petugas pendamping program CSR Badak LNG. Sehingga nilai rata - rata tingkat kinerja dari indikator Kejelasan Petugas/Pendamping adalah sebesar 3,24, yang berarti indikator kejelasan Petugas pendamping program CSR Badak LNG dalam kondisi mutu BAIK. Dilihat dari tingkat kepentingan untuk indikator kejelasan petugas/pendamping dapat kita lihat pada gambar 4. Dari gambar 4 ini terlihat bahwa $39 \%$ masyarakat penerima manfaat program CSR Badak LNG menyatakan penting dan $58 \%$ menyatakan sangat penting. Bagi masyarakat kejelasan petugas / pendamping program adalah sangat berguna karena dapat meningkatkan peran serta aktif masyarakat dalam mengsukseskan program CSR Badak 
LNG tersebut, sehingga capaian yang telah ditargetkan dapat terlaksana.

Dari hasil tingkat kinerja dan tingkat kepentingan terhadap indikator kejelasan petugas pendamping di peroleh tingkat kesesuaian sebesar $91 \%$ yang artinya bahwa kepentingan masyarakat terpenuhi dengan baik sebanyak $91 \%$.

\section{Kedisiplinan Petugas / Pendamping}

Indikator kedisiplinan petugas pelayanan progran CSR Badak LNG terdiri dari dua sub indikator yaitu tingkat kredibilitas petugas/pendamping program dan indikator tingkat kesesuaian jadwal pendampingan dengan pelaksanaan bantuan.

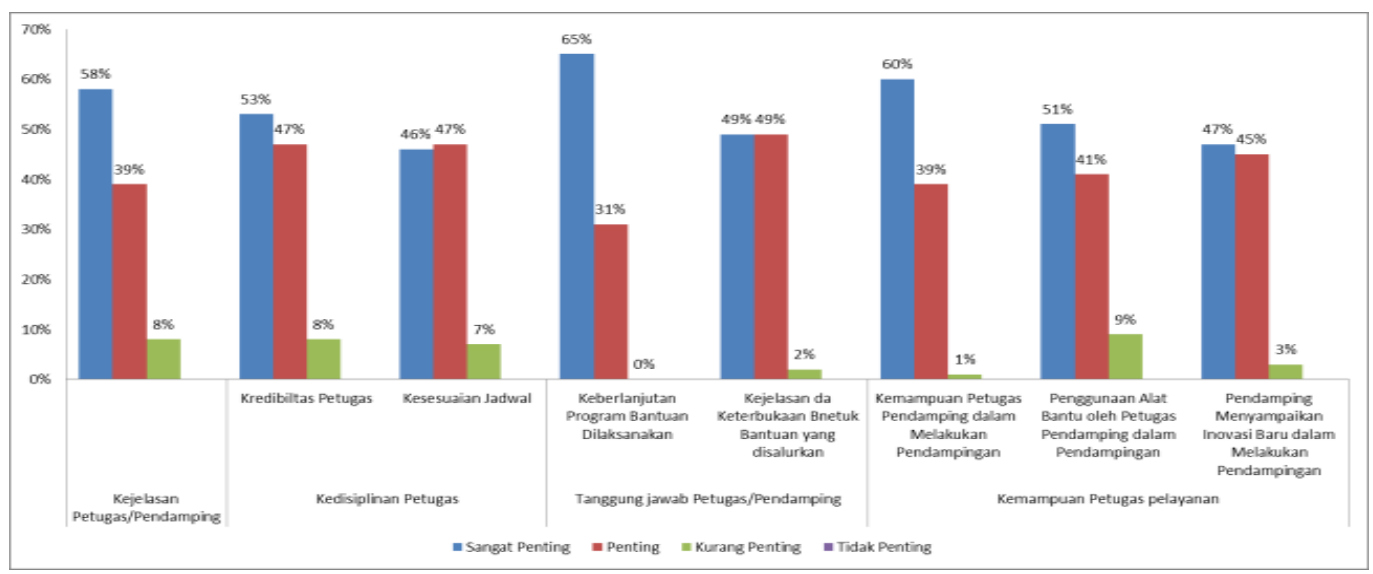

Gambar 6. Tingkat Kepentingan Petugas Pendamping

Indikator kedisiplinan pelayanan program CSR Badak LNG dapat kita lihat pada gambar 5 bahwa penerima manfaat menilai $29 \%$ responden menyatakan sangat puas dan 50\% puas terhadap kredibilitas petugas pendamping, dan $20 \%$ responden menilai puas, 59\% sangat puas terhadap kesesuaian jadwal pendamping dengan jadwal pelaksanaan program CSR Badak LNG.

Nilai rata-rata indikator kedisiplinan petugas/pendamping diperoleh nilai sebesar 3,08 . Berdasarkan rentang skor yang ada dapat di katakan bahwa kinerja kedisiplinan petugas pelayanan program CSR Badak LNG berada adalam kondisi BAIK. Persepsi masyarakat terhadap kepentingan indikator kedisplinan petugas dan pelayanan dapat kita lihat pada gambar 6 .

Dari gambar 6, tergambar kepentingan/harapan masyarakat terhadap indikator kredibilitas petugas / pendamping sebesar $47 \%$ menyatakan penting dan $53 \%$ menyatakan sangat penting, sedangkan sub indikator kesesuaian Jadwal pendamping dengan jadwal pelaksanaan program CSR Badak LNG sebesar $47 \%$ penerima manfaat menyatakan penting kesesuaian jadwal pendamping dan $46 \%$ menyatakan sangat penting. Tingkat kesesuaian antara tingkat kinerja perusahaan dengan tingkat kepentingan masyarakat terhadap indikator Kedisiplinan Petugas / Pendamping yang di peroleh nilai kesesuaiannya yaitu sebesar $89 \%$.

\section{Tanggung jawab Petugas/ Pendamping}

Indikator tanggung jawab petugas/ pendamping terdapat dua sub indikator yaitu sub indikator tingkat keberlanjutan program dan tingkat kejelasan dan keterbukaan terhadap bentuk bantuan yang disalurkan melalui program CSR Badak LNG. Indikator pelayanan ini terkait dengan tanggung jawab petugas/pendamping terhadap dampak keberlanjutan manfaat yang telah di berikan dan tanggung jawab petugas/pendamping pelayanan program dalam

Petugas menyampaikan jenis Bantuan yang akan diberikan, sehingga masyarakat mengetahui dan merasa tidak ada informasi yang tertutup. 
Dari gambar 5, tingkat kinerja pada sub indikator keberlanjutan program, dinilai oleh penerima manfaat sebesar $37 \%$ puas dan $30 \%$ sangat puas, dan indikator kejelasan dan keterbukaan bentuk bantuan yang disalurkan kepada masyarakat sebesar $51 \%$ menyatakan puas dan ada $9 \%$ yang menyatakan kurang puas.

Di lihat dari tingkat kepentingan masyarakat (gambar 4), sub indikator keberlanjutan program dinilai oleh masyarakat sebesar $31 \%$ menyatakan penting dan $65 \%$ menyatakan sangat penting. Nilai rata-rata (NRR) tingkat kepentingan Indikator Tanggung jawab petugas/pendamping diperoleh nilai sebesar 3,53.

Di lihat dari tingkat kesesuaian antara tingkat kinerja dan tingkat kepentingan di peroleh nilai 95 persen, artinya kepentingan masyarakat telah terpenuhi dengan baik sebesar 95 persen.

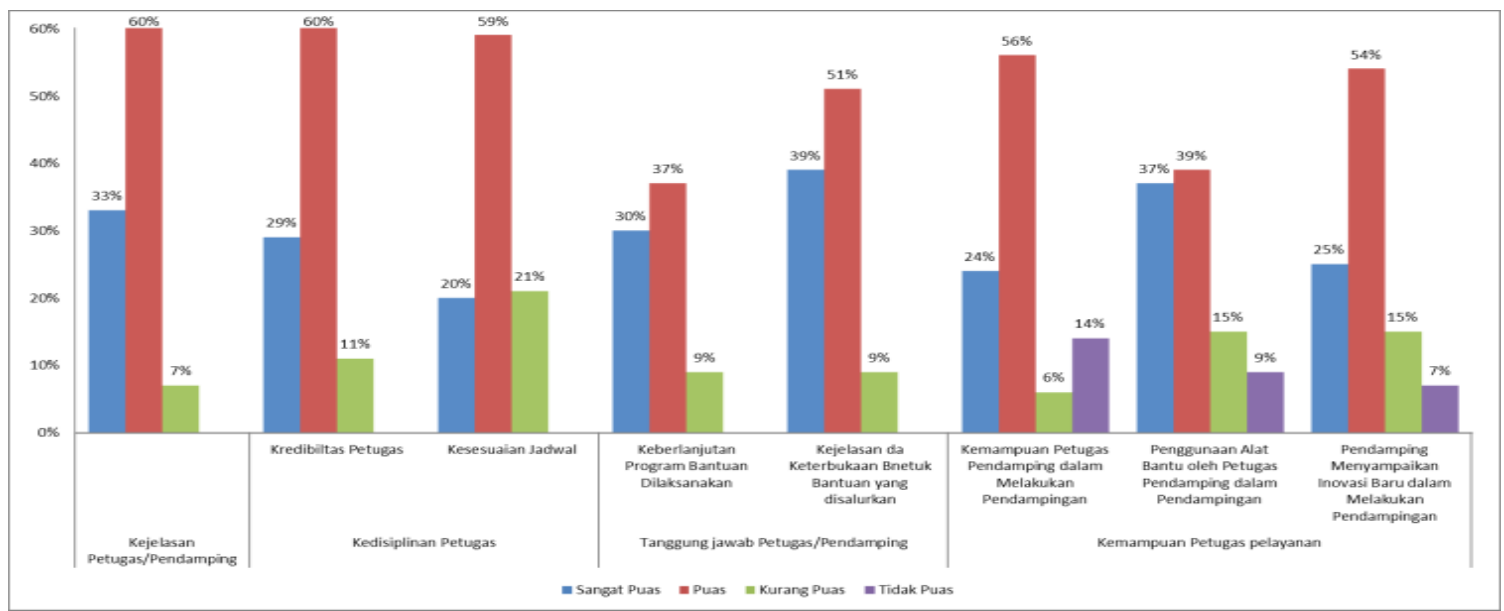

Gambar 7. Tingkat Kinerja Pegawai/Pendamping Program

\section{Kemampuan Petugas Pelayanan}

Indikator kemampuan petugas pada evaluasi ini terdiri dari tiga sub indikator yaitu tingkat kemampuan petugas/pendamping dalam melakukan pendampingan program bantuan, pettugas menggunakan alat bantu Nilai rata-rata(NRR) tingkat kinerja memperoleh nilai 3,32 yang artinya sangat baik, Sebagian besar penerima manfaat meilai puas terhadap tingkat kinerja kemampuan petugas/pendamping. Sedangkan persepsi tingkat kepentingan masyarakat terhadap indikator kemampuan petugas/pendamping dapat kita lihat pada gambar 6 .

Nilai rata-rata tingkat kepentingan masyarakat terhadap indikator Kemampuan petugas/pendamping sebesar 3,48 dengan demikian pelayanan ini sangat penting bagi masyarakat penerima manfaat. Dilihat dari dalam pendampingan, dan sub indikator petugas/pendamping menyampaikan teknologi dan inovasi baru dalam kegiatan pendampingan. Persepsi masyarakat terhadap tingkat kinerja kemampuan petugas dapat kita lihat pada gambar 5 .

tingkat kesesuaian antara kinerja perusahaan dengan kepentingan masyarakat maka di peroleh nilai kesesuaian sebesar $95 \%$ hal ini menunjukkan bahwa kepentingan masyarakat sudah terpenuhi dengan sangat baik bahkan melebihi hingga $95 \%$.

\section{Kecepatan Pelayanan}

Indikator kecepatan pelayanan pada evaluasi ini terdiri dari dua sub indikator yaitu tingkat ketepatan waktu pengajuan dan realisasi program bantuan, serta indikator ketepatan waktu petugas/pendamping dalam pelaksanaan program bantuan CSR Badak LNG. Hasil 
indeks kepuasan masyarakat terhadap indikator kecepatan pelayanan dapat kita lihat gambar 8 .

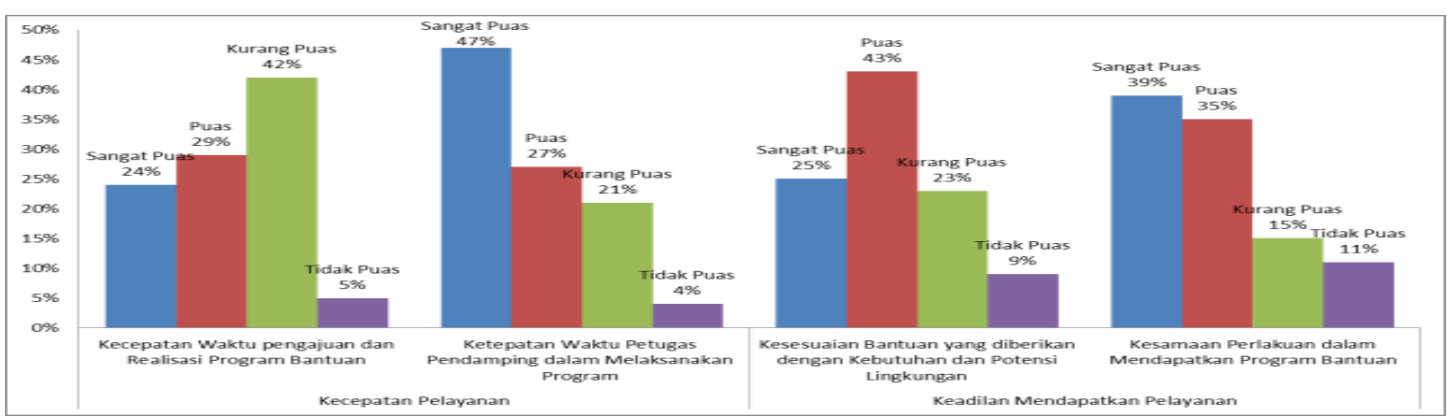

Gambar 8. Tingkat Kinerja Perusahaan dengan Indikator Kecepatan Pelayanan dan Keadilan

\section{Pelayanan}

Dari gambar 8 terlihat bahwa dalam sub indikator kecepatan waktu pengajuan dan realisasi program, masyarakat penerima manfaat memberikan pernyataan puas sebanyak $29 \%$ sedangkan masyarakat yang menyatakan kurang puas sebanyak $42 \%$ hal ini terjadi karena masayarakat mengangap bahwa waktu antara mengajukan proposal bantuan dengan realiasi program sangat lama bahkan memakan waktu hingga beberapa bulan, sementara sub indikator ketepatan waktu petugas pendamping dalam melaksanakan program, sebanyak $47 \%$ masyarakat penerima manfaat menyatakan puas dan terdapat $21 \%$ masyarakat penerima manfaat menyatakan kurang puas

Gambar 9. Tingkat Kepentingan Masyarakat terhadap Indikator Kecepatan Pelayanan dan Keadilan Pelayanan

Persepsi masyarakat terkait tingkat kepentingan pada indikator kecepatan pelayanan dapat kita lihat pada gambar 9. Dari gambar 9 terlihat bahwa indikator kecepatan pelayanan merupakan hal yang dianggap penting oleh masyarakat penerima manfaat, sebanyak $45 \%$ masyarakat menyatakan kecepatan pelayanan penting dan $45 \%$ sangat penting. Dilihat dari nilai rata - rata (NRR) tingkat kinerja terkait indikator kecepatan pelayanan, masyarakat penerima manfaat menilai sebesar 3,26, sedangkan nilai rata - rata (NRR) tingkat kepentingan terkait indikator kecepatan pelayanan sebesar 3,45. Dilihat dari tingkat kesesuaian antara tingkat kinerja dan tingkat kepentingan, terdapat nilai kesesuaian 
sebesar $94 \%$ yang artinya kepentingan sudah terpenuhi dengan baik. masyarakat baru terpenuhi sebanyak $94 \%$

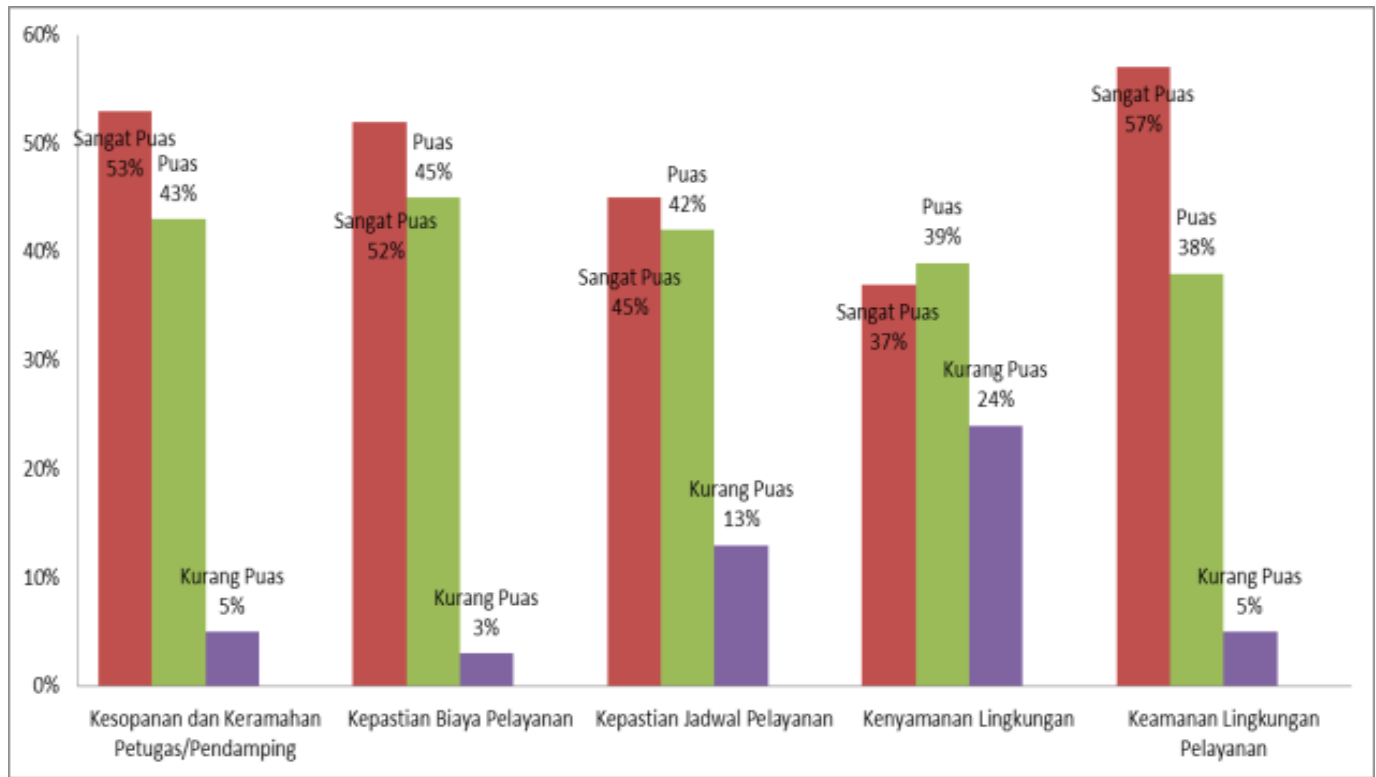

Gambar 10. Tingkat Kinerja Perusahaan pada Indikator Kesopanan hingga Keamanan Lingkungan

Pelayanan

\section{Keadilan Mendapatkan Pelayanan Indikator}

Dari gambar 8 terlihat bahwa tingkat kesesuaian bantuan dengan kebutuhan dan potensi lingkungan, masyarakat penerima manfaat menilai puas sebanyak $43 \%$ dan kurang puas sebanyak $23 \%$, sementara tingkat kesamaan perlakukan dalam mendapatkan pelayanan program bantuan CSR Badak LNG, masyarakat penerima manfaat menyatakan puas sebanyak $35 \%$ dan kurang puas sebanyak $15 \%$.

Dari gambar 9 terlihat bahwa tingkat kepentingan masyarakat pada sub indikator kesesuaian bantuan dengan kebutuhan dan potensi lingkungan, masyarakat penerima manfaat menyatakan sangat penting sebanyak $60 \%$ dan penting sebanyak $37 \%$. Nilai rata rata (NRR) tingkat kinerja dari indikator keadilan mendapatkan pelayanan sebesar 3,01, sedangkan nilai rata-rata (NRR) tingkat kepentingan pada indikator keadilan mendapatkan pelayanan sebesar 3,53 Nilai

\section{Kesopanan dan Keramahan Petugas /} Pendamping

Indikator kesopanan dan keramahan petugas / pendamping terdiri dari satu sub indikator yaitu tingkat kesopanan dan keramahan petugas / pendamping dalam proses pendampingan. Tingkat kinerja indikator ini dapat kita lihat pada gambar 10 .

Dari gambar 10 masyarakat penerima manfaat menilai tingkat kesopanan dan keramahan petugas pendamping dalam proses pendampingan menyatakan puas sebanyak $43 \%$ dan yang menyatakan sangat puas sebanyak 53 $\%$.

Dari gambar 11 terlihat bahwa masyarakat penerima manfaat menyatakan penting sebanyak $41 \%$ dan sangat penting sebanyak $59 \%$ terhadap indikator kesopanan dan keramahan petugas/pendamping dalam proses pendampingan.

Nilai rata-rata (NRR) tingkat kinerja pada indikator kesopanan dan keramahan petugas /pendamping adalah sebesar 3,5, sedangkan Nilai rata-rata (NRR) tingkat kepentingan pada indikator kesopanan dan keramahan petugas/pendamping adalah sebesar 3,59, sehingga di peroleh nilai tingkat kesesuaian antara tingkat kinerja dan tingkat kepentingan sebesar $97 \quad \% \quad$ yang artinya kepentingan masyarakat telah terpenuhi sangat 
baik hingga melebihi harapan yaitu sebesar $97 \%$.

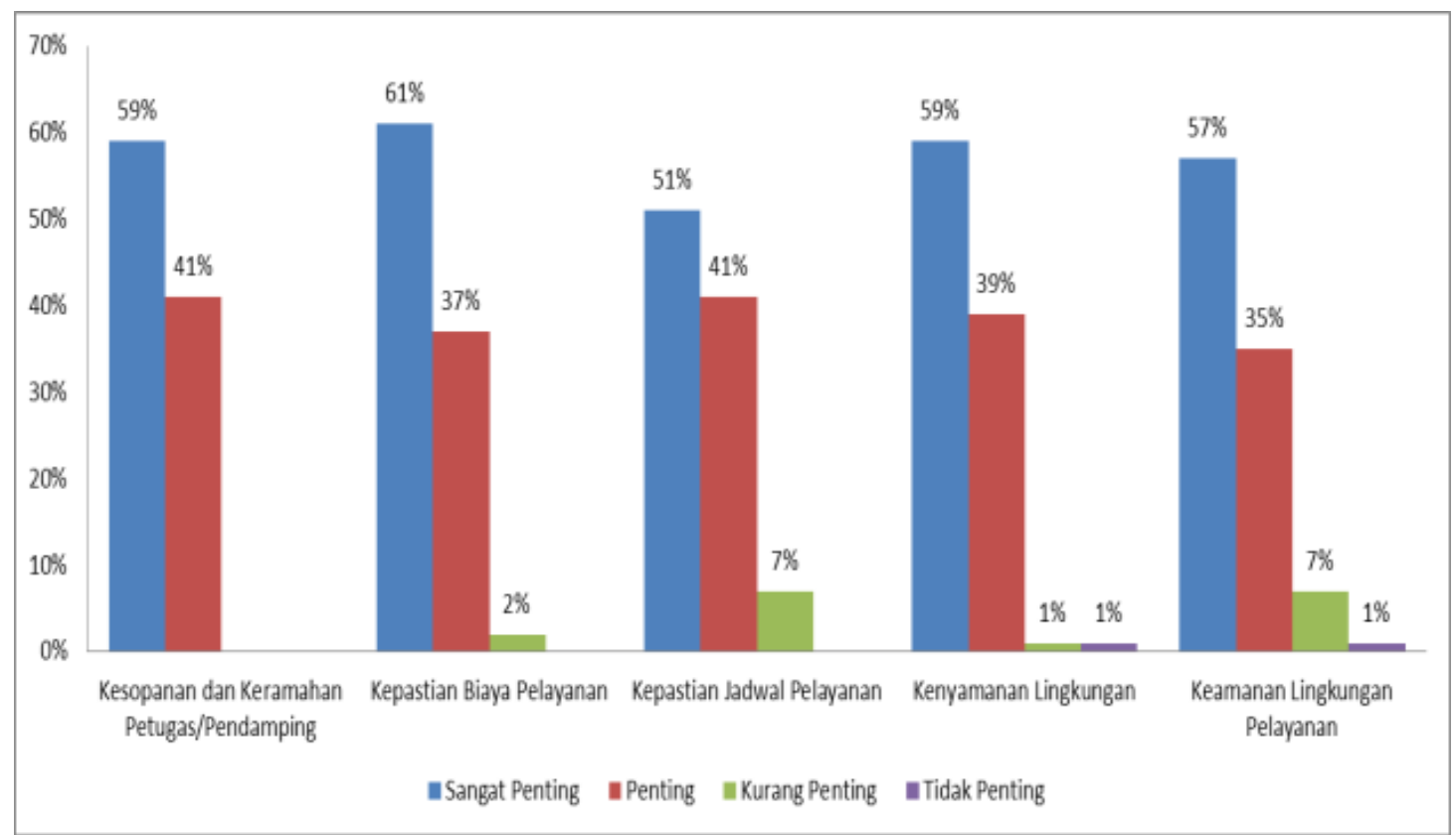

Gambar 11. Tingkat Kepentingan Masyarakat terhadap Indikator Kesopanan hingga Keamanan Lingkungan Pelayanan

\section{Kepastian Biaya Pelayanan}

Indikator kepastian biaya pelayanan terdapat satu sub indikator yaitu tidak dikenakan biaya kepada peserta program CSR Badak LNG. Gambar 8 terlihat bahwa tingkat kepuasan masyarakat terhadap indikator kepastian biaya pelayanan.

Terlihat bahwa masyarakat penerima manfaat program CSR Badak LNG sebanyak 45 $\%$ menyatakan puas dan $52 \%$ menyatakan sangat puas. Sementara itu persepsi tingkat kepentingan masyarakat penerima manfaat dapat kita lihat pada gambar 11. Sebagian besar masyarakat penerima manfaat menyatakan penting sebesar $37 \%$ dan menyatakan sangat penting sebanyak $61 \%$. Nilai rata - rata tingkat kinerja pada indikator Kepastian Biaya Pelayanan adalah sebesar 3,2, sedangkan nilai rata - rata tingkat kepentingan pada indikator ini sebanyak 3,4, sehingga nilai tingkat kesesuaian antara tingkat kinerja dan tingkat kepentingan adalah sebesar $97 \%$, hal ini menggambarkan bahwa kepentingan dan harapan masyarakat terkait indikator kepastian biaya pelayanan telah terpenuhi dengan baik serta melebihi harapan sebanyak $97 \%$.

\section{Kepastian Jadwal Pelayanan}

Indikator kepastian jadwal pelayanan terdiri dari satu sub indikator yaitu kepastian jadwal pendampingan dan pemberian program. Kepastian jadwal pelayanan dan pendampingan yang di berikan kepada masyarakat penerima manfaat ini disesuaikan dengan waktu penerima manfaat. Persepsi masyarakat terhadap indikator kepastian jadwal kegiatan ini terlihat pada gambar 8 masyarakat penerima manfaat menyatakan puas sebanyak $42 \%$ dan masyarakat yang menyatakan tidak puas sebanyak $13 \%$.

Tingkat kepentingan masyarakat terhadap indikator kepastian jadwal pendampingan dan pemberian program tergambar pada gambar 11 menunjukkan $41 \%$ masyarakat penerima manfaat menyatakan indikator ini penting dan yang menyatakan sangat penting sebanyak $51 \%$.

Nilai rata - rata tingkat kinerja pada indikator kepastian jadwal pelayanan ini adalah sebesar 3,12, dan nilai rata- rata tingkat 
kepentingan pada indikator kepastian jadwal pelayanan adalah sebesar 3,56, sehingga nilai kesesuaian antara tingkat kepentingan dengan tingkat kinerja adalah sebesar $88 \%$ yang artinya kepentingan atau harapan masyarakat penerima manfaat terpenuhi dengan baik sebesar $88 \%$.

\section{Kenyamanan Lingkungan}

Indikator kenyamanan lingkungan terdiri dari satu sub indikator yaitu kenyamanan lingkungan tempat kegiatan pendampingan program CSR Badak LNG. Kenyamanan lingkungan yang dimaksud yaitu pelayanan tempat atau lokasi yang sesuai dengan kebutuhan program bantuan yang di berikan kepada masyarakat penerima manfaat. Pada gambar 10 kita dapat melihat persepsi masyarakat penerima manfaat terhadap indikator kenyamanan lingkungan tempat pelaksanaan program, tergambar bahwa $39 \%$ masyarakat penerima manfaat menyatakan Puas dan $37 \%$ menyatakan sangat puas, terdapat $24 \%$ yang menyatakan kurang puas.

Persepsi tingkat kepentingan masyarakat penerima manfaat terhadap indikator kenyamanan lingkungan tergambar pada gambar 11. Sebanyak $39 \%$ masyarakat menyatakan penting dan sebanyak $59 \%$ menyatakan sangat penting.

Nilai rata - rata tingkat kinerja terhadap indikator kenyamanan lingkungan adalah sebesar 3,52, sedangkan nilai rata - rata tingkat kepentingan masyarakat terhadap indikator kenyamanan lingkungan adalah sebesar 3,49, sehingga nilai tingkat kesesuaian antara tingkat kinerja dan tingkat kepentingan adalah sebesar $101 \%$ yang artinya, kepentingan atau harapan masyarakat terhadap kenyamanan lingkungan telah terpenuhi dengan baik sebesar $101 \%$.

\section{Keamanan Lingkungan Pelayanan}

Indikator keamanan pelayanan terdiri dari satu sub indikator yaitu keamanan lingkungan tempat kegiatan pendampingan program bantuan CSR Badak LNG. Keamanan pelayanan yang diberikan kepada masyarakat penerima manfaat program yaitu suatu bentuk pelayanan berupa kondisi lingkungan yang tidak membahayakan saat dilaksanakannya pelatihan/pendampingan program bantuan. Persepsi masyarakat terhadap indikator keamanan lingkungan Pelayanan ditunjukkan pada gambar 10, sebagian besar masyarakat penerima manfaat menyatakan puas $38 \%$ terhadap keamanan pelayanan dan $57 \%$ yang menyatakan sangat puas.

Sedangkan persepsi masyarakat pada tingkat kepentingan terhadap indikator keamanan lingkungan pelayanan dapat di lihat pada gambar 9 bahwa $35 \%$ masyarakat menyatakan penting dan $57 \%$ menyatakan sangat penting.

Nilai rata - rata tingkat kinerja pada indikator keamanan lingkungan pelayanan adalah sebesar 3,58 dan nilai rata - rata tingkat kepentingan adalah sebesar 3,55 , sehingga nilai tingkat kesesuaian pada indikator keamanan lingkungan pelayanan adalah sebesar $101 \%$ yang artinya kepentingan atau harapan masyarakat penerima manfaat telah terpenuhi dengan baik bahkan melebihi harapan sebanyak $101 \%$.

\section{Tingkat Kesesuaian antara Tingkat Kinerja dan Tingkat Kepentingan Program CSR Badak LNG}

Merupakan perbandingan antara tingkat kinerja dengan tingkat kepentingan. Tingkat kinerja adalah segala sesuatu yang telah dilakukan oleh perusahaan untuk melayani masyarakat penerima manfaat, sedangkan tingkat kepentingan adalah harapan masyarakat penerima manfaat mengenai barang atau jasa yang ditawarkan perusahaan. Dalam hal ini apabila tingkat kesesuaian mencapai $100 \%$ maka masyarakat dapat di katakan puas terhadap kinerja, tetapi apabila tingkat kesesuaian kurang dari $100 \%$, maka masyarakat belum merasa puas terhadap pelayanan program bantuan CSR perusahaan, hal ini berarti pelayanan program bantuan belum memenuhi harapan masayrakat penerima manfaat. Nilai kesesuaian pada masing - 
masing unsur pelayanan dapat kita lihat pada tabel 7.

Dari tabel 7 menunjukkan ada beberapa unsur pelayanan yang masih berada di bawah $100 \%$ dan juga terdapat beberapa unsur pelayanan yang melebihi harapan penerima manfaat hingga mencapai $101 \%$. Secara keseluruhan tingkat kesesuaian antara kepuasan kinerja dengan kepentingan masyarakat adalah sebesar $94 \%$ atau sangat baik, artinya keseluruhan kepentingan masyarakat sudah terpenuhi dengan baik sebesar $94 \%$. Oleh karena itu perusahaan di harapkan dapat mempertahankan serta meningkatkan kinerjanya supaya tingkat kesesuaian antara kinerja dengan kepentingan dapat mencapai angka $100 \%$ bahkan lebih.

\begin{tabular}{|c|c|c|c|c|}
\hline No & Unit Pelayanan & $\begin{array}{l}\text { Indeks } \\
\text { Kinerja }\end{array}$ & $\begin{array}{c}\text { Indeks } \\
\text { Kepentingan }\end{array}$ & $\begin{array}{l}\text { Tingkat } \\
\text { Kesesuaiar }\end{array}$ \\
\hline 1 & Prosedur Pelayanan & 3,01 & 3,46 & $87 \%$ \\
\hline 2 & Persyartan pelayanan & 3,07 & 3,52 & $87 \%$ \\
\hline 3 & Kejelasan Petugas / Pendamping & 3,24 & 3,55 & $91 \%$ \\
\hline 4 & Kedisiplinan Petugas / Pendamping & 3,08 & 3,45 & $89 \%$ \\
\hline 5 & Tangoungjawanan Petugas / Pendamping & 3,35 & 3,53 & $95 \%$ \\
\hline 6 & $\begin{array}{l}\text { Kemampunan Petugas / Pendamping } \\
\text { dalam Pelayanan }\end{array}$ & 3,32 & 3,48 & $95 \%$ \\
\hline 7 & Kecepatan Pelayanan & 3,26 & 3,45 & $94 \%$ \\
\hline 8 & Keadllan Mendapatkan Pelayanan & 3,01 & 3,53 & $85 \%$ \\
\hline 9 & $\begin{array}{l}\text { Kesopanan \& Keramahan Petugas / } \\
\text { Pendamping }\end{array}$ & 3,5 & 3,59 & $97 \%$ \\
\hline 10 & Kewajaran Biaya Pelayanan & 3,66 & 3,6 & $102 \%$ \\
\hline 11 & Kepastian Biaya Pelayanan & 3,32 & 3,44 & $97 \%$ \\
\hline 12 & Kepastian Jadwa Pelayanan & 3,12 & 3,56 & $88 \%$ \\
\hline 13 & Kenyamanan Lingkungaan & 3,52 & 3,49 & $101 \%$ \\
\hline 14 & Keamanan Lingkungan & 3,58 & 3,55 & $101 \%$ \\
\hline & Nilai Indeks & 3,27 & 3,49 & $94 \%$ \\
\hline
\end{tabular}

Gambar 11. Nilai Kesesuaian Pada Masing Masing

Unsur Pelayanan Program CSR Badak LNG

Berdasarkan hasil perhitungan tingkat kesesuaian antara penilaian tingkat kinerja dan tingkat kepentingan dari indikator kualitas pelayanan. Di peroleh gambar diagram cartesius yang menunjukkan posisi sebuah indikator pada kuadran tertentu dapat kita lihat pada gambar 11.

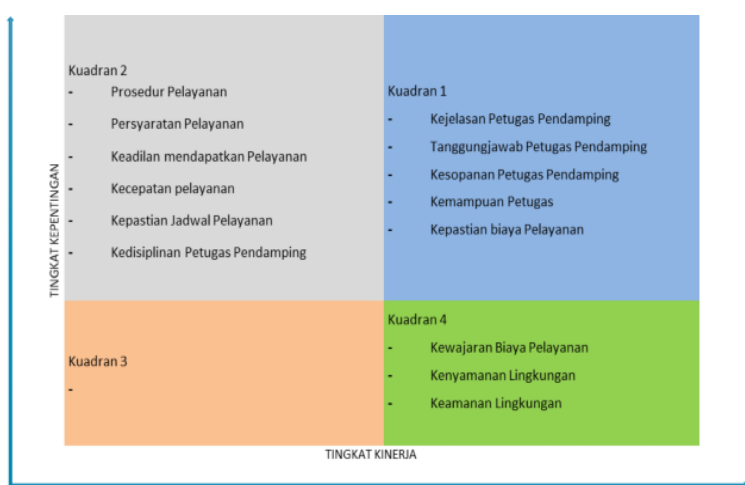

Gambar 12. Diagram Cartesius dari Indikator indikator Pelayanan Program CSR Badak LNG Tahun 2015-2016

Hasil dari analisis Importance Performance Analysis (IPA) yaitu berupa sebuah diagram yang dibagi kedalam empat kuadran. Masing masing kuadran terdapat beberapa indikator pelayanan program CSR Badak LNG. Penjelasan mengenai masing - masing kuadran pada diagram tingkat kepentingan dan tingkat kinerja perusahaan terhadap warga masyarakat penerima manfaat program CSR Badak LNG akan di uraikan sebagai berikut :

Kuadran I (High importance \& High Performance )-

K.I Indikator-indikator yang masuk dalam kuadran ini adalah yang memiliki harapan tinggi dari masyarakat penerima manfaat dan kinerja yang tinggi dari perusahaan. Sehingga pihak perusahaan perlu mempertahankan prestasi kinerjanya karena dengan begitu citra perusahaan dalam pengembangan masyarakat akan tetap baik. Beberapa indikator yang masuk dalam kuadran ini adalah :

1. Kejelasan petugas pendamping,

2. Tanggung jawab petugas pendamping,

3. Kemampuan Petugas Pendamping,

4. Kesopanan Petugas Pendamping dan

5. Kepastian biaya pelayanan 
Kuadran II (High importance \& Low Performance)- K.II

Pada kuadran ini terdapat indikator yang berkinerja rendah tetapi mempunyai kepentingan yang tinggi. Tingkat kepentingan yang tinggi mencerminkan bahwa masyarakat penerima manfaat program mempunyai harapan tinggi terhadap indikator - indikator tersebut. Jadi indikator yang terdapat dalam kuandran II ini perlu mendapat prioritas utama dari pihak perusahaan untuk dilakukan perbaikan program. Indikator yang berada di pada kuadran ini adalah:

1. Prosedur pelayanan

2. Persyaratan pelayanan

3. Keadilan mendapatkan pelayanan

4. Kecepatan pelayanan

5. Kepastian jadwal pelayanan

6. Kedisiplinan petugas

Kuadran III (Low Importance \& Low Performance)

\section{- K.III}

Pada kuadran III ini terdapat beberapa indikator penilaian dengan tingkat kepentingan dan tingkat kinerja yang rendah. Walaupun indikator yang terdapat dalam kuadran ini dianggap tidak terlalu penting oleh masyarakat, hendaknya perusahaan selalu meningkatkan kinerjanya karena tingkat kepentingan masyarakat penerima manfaat program dapat meningkat tergantung kebutuhannya.

Kuadran IV (Low Importance \& High Performance)-K.IV

Kuadran IV memuat indikator yang dirasa kurang penting oleh masyarakat, namun tingkat kinerja perusahaan di rasa berlebih. Perusahaan hendaknya tidak terlalu menjadikan indikator penilaian pada kuadran ini sebagai prioritas karena hanya akan terjadi pemborosan biaya. Indikator - indikator yang terdapat dalam kuadran IV ini adalah:

1. Kewajaran biaya pelayanan

2. Kenyaman lingkungan dan

3. Keamanan lingkungan
Untuk menganalisis dampak program pada CSR Badak LNG ini menggunakan alat Compass Sustainability Analysis. Alat ini bertujuan untuk melihat dampak - dampak program yang telah di jalankan dalam kurun 5 (lima) tahun terakhir dengan 4 Dimensi sesuai dengan arah mata angin yang di simbolkan sebagai berikut : $\mathrm{N}=$ Nature, $\mathrm{W}=$ Wellbeing, $\mathrm{E}=$ Economy, $\mathrm{S}=$ Social.

Dampak program CSR Badak LNG terhadap lingkungan dan kehidupan masyarakat berdasarkan hasil analisa Compass Sustainability Analysis Indicator adalah sebagai berikut.

Tabel 5. Analisa Dampak Program CSR Badak LNG

\begin{tabular}{lclr}
\hline No & Dimensi & \multicolumn{2}{c}{ Dampak Program } \\
\hline 1 & Nature & Terjaganya & Kualitas \\
& & Sungai dan & Mangrove \\
& & yang ada di Pesisir Kota
\end{tabular}

Bontang

Terpeliharanya

ekosistem Terumbu

Karang melalui

transplantasi terumbu

karang bioreeftech

Tertanamnya $\quad 100.000$

bibit mangrove di 10 ha

luasan mangrove rusak telah di rehabilitasi.

Teridentifikasi 19 Jenis

Mangrove yang ada dipesisir Kota Bontang

Pemanfaatan Hasil

Hutan Bukan Kayu (HHBK) melalui

Diversifikasi Mangrove

(Batik Mangrove, Sirup

Mangrove, Panganan

Mangrove)

Pemanfaatan Jasa

Lingkungan Mangrove

melalui ekowisata

mangrove di Kawasan

Sungai Belanda Bontang

Kuala dan Ekowisata

Managrove di Tanjung

Laut Indah 


\begin{tabular}{|c|c|c|c|}
\hline \multirow[t]{23}{*}{2} & \multirow[t]{23}{*}{ Economy } & Adanya $\quad$ Peningkatan & ekonomi dan usaha. \\
\hline & & pendapatan anggota & Terbangun kepercayaan \\
\hline & & kelompok mitra binaan & masyarakat khususnya \\
\hline & & antara Rp. $500.000 \quad-$ & terkait pelestarian SDA \\
\hline & & Rp.2.000.000,- per bulan & di pesisir. \\
\hline & & 676 Rumah Tangga & Terbangunnya \\
\hline & & Miskin menerima & kawasan mangrove \\
\hline & & manfaat langsung. & menjadi \\
\hline & & 16 Kelompok Mitra & ekowisata dan \\
\hline & & Binaan mampu & pendidingan lingkungan \\
\hline & & mengelola & hidup \\
\hline & & secara mandiri, 4 di & $68 \%$ Masyarakat yang \\
\hline & & antaranya telah menjadi & tergabung dalam \\
\hline & & Mitra Kerjasama & kelompok mitra binaan \\
\hline & & Aset \& Omzet Kelompok & merasakan manfaat dari \\
\hline & & mitra binaan meningkat & program CSR Badak. \\
\hline & & hingga $70 \%$ & 36 Kelompok mitra \\
\hline & & Terbukanya & binaan memperoleh \\
\hline & & produk kelompok mitra & peningkatan kapasitas \\
\hline & & binaan melalui pameran- & melalui pelatihan - \\
\hline & & pameran yang di ikuti. & pelatihan dan study \\
\hline & & Jumlah kelompok terus & banding \\
\hline & & berkembang. & kelompok 1 \\
\hline \multirow[t]{23}{*}{3} & \multirow[t]{23}{*}{ Social } & Terlindunginya hak - & dengan kelompok lain \\
\hline & & hak masyarakat untuk & terjalin kerjasama untuk \\
\hline & & mengakses sumber daya & menghasilkan \\
\hline & & pesisir, Laut dan & produksi. \\
\hline & & Mangrove. & Tingkat \\
\hline & & Pemanfaatan & masyarakat sangat baik \\
\hline & & Hutan Bukan & dengan Indeks Kepuasan \\
\hline & & (HHBK) melalui & Masyarakat 3,27 dalam \\
\hline & & Diversifikasi Mangrove & Kategori Sangat Baik. \\
\hline & & (Batik Mangrove, Sirup & \\
\hline & & Mangrove, Panganan & \multirow{13}{*}{$\begin{array}{l}\text { Apabila ditelaah lebih jauh, intisari dari } \\
\text { program CSR sejatinya tidak hanya menitik } \\
\text { beratkan pada aspek manusia. Program CSR tak } \\
\text { harus selalu berorientasi pada upaya } \\
\text { peningkatan kesejahteraan secara langsung. Hal } \\
\text { inilah yang sebenarnya perlu mendapat } \\
\text { perhatian lebih jauh. Mengingat dewasa ini } \\
\text { kebanyakan program CSR terlalu } \\
\text { menitikberatkan pada aspek pemberdayaan } \\
\text { sumber daya manusia dan upaya peningkatan } \\
\text { kesejahteraan saja. Belum ada upaya inklusif } \\
\text { untuk mencapai unsur pembangunan } \\
\text { berkelanjutan yang melibatkan daya dukung } \\
\text { alam sebagai salah satu instrumen utama dalam } \\
\text { program pemberdayaan. }\end{array}$} \\
\hline & & Terbentuknya budaya & \\
\hline & & masyarakat pesisir yang & \\
\hline & & dulunya mengebom & \\
\hline & & sekarang tidak lagi & \\
\hline & & Terbentuknya budaya & \\
\hline & & masyarakat & \\
\hline & & menebang & \\
\hline & & mangrove dengan & \\
\hline & & $\begin{array}{l}\text { sekarang tidak lagi dan di } \\
\text { manfaatkan. }\end{array}$ & \\
\hline & & Ada budaya masyarakat & \\
\hline & & berkelompok dalam & \\
\hline & & melakukan kegiatan & \\
\hline
\end{tabular}


Implementasi dan evaluasi program CSR Badak LNG mulai memandang lingkungan sebagai satu elemen penting yang harus dijaga. Hal itu terlihat dari programprogram yang dijalankan dan telah dipandang berhasil. Beberapa program seperti penanaman kembali lahan mangrove, pelestarian kawasan pesisir, program perbaikan terumbu karang. Semua program tadi tidak ditujukan untuk meningkatkan kesejahteraan masyarakat sebagai tujuan utama. Lebih daripada itu, programprogram tersebut merupakan proyek pembangunan berkelanjutan. Tujuannya tak lain adalah untuk melestarikan lingkungan dan meningkatkan daya dukung alam dalam jangka panjang. Setelah itu, baru peningkatan kesejahteraan masyarakat akan ikut bergerak naik seiring dengan perbaikan kualitas lingkungan hidup.

Dalam konsep Green Economy, perekonomian yang tumbuh harus diikuti dengan perbaikan kualitas lingkungan hidup. Alam tidak boleh rusak akibat aktivitas ekonomi. Pembangunan ekonomi harus selaras dengan lingkungan. Akan tetapi, konsep yang berkembang dewasa ini tidak demikian. Perekonomian bergerak dengan mengeksploitasi alam. Lingkungan seolah-olah hanya menjadi penyedia faktor produksi. Dalam pandangan ekonomi, ini disebut dengan brown economics.

Dalam CSR yang dilakukan oleh Badak LNG, terdapat paradigma yang ingin dirubah melalui serangkaian program pelestarian lingkungan. Masyarakat diedukasi bahwa lingkungan adalah pinjaman dari anak cucu yang harus dilestarikan. Pembangunan yang dilakukan tidak boleh merusak alam. Sedangkan, daya dukung alam harus selalu ditingkatkan dengan cara melakukan serangkaian program pelestarian. Mengingat Kota Bontang terletak di pesisir, maka perbaikan lingkungan yang dilakukan adalah dengan pelestarian kawasan perairan dan pantai berikut upaya menjaga biodiversitas yang ada di dalamnya.

Program ini dirasakan berhasil apabila mengacu pada hasil evaluasi seperti yang telah dipaparkan di bagian awal pembahasan. CSR yang dilakukan dianggap telah mampu untuk turut melestarikan lingkungan. Hal ini terlihat dari hasil program yang dapat langsung dirasakan hasilnya mulai dari terbentuknya kelompok komunitas ekowisata, reboisasi kawasan mangrove dan hilir sungai, serta mulai berkembangnya program transplantasi terumbu karang. Adapun secara tidak langsung, aktivitas ekonomi masyarakat mulai bergeliat naik.

Dengan meningkatnya daya dukung lingkungan, masyarakat melalui program CSR telah mampu mengembangkan diri dan meningkatkan kesejahteraannya melalui serangkaian aktivitas. Pola pemberdayaan pun juga bersifat partisipatif dan melibatkan kelompok-kelompok. Sehingga lebih banyak masyarakat yang terlibat. Akibatnya, makin banyak pula masyarakat yang mulai merasakan hasilnya.

Masyarakat kini mulai dapat memanfaatkan hasil hutan mangrove untuk mendukung usaha. Mulai dari kegiatan jasa pariwisata hingga pemanfaatan hasil hutan mangrove untuk bahan baku UKM seperti pembuatan sirup, membuat pewarna untuk batik dan makanan ringan berbahan dasar tanaman mangrove.

Proses ini tentu saja diawali dari inisiatif Badak LNG untuk memberdayakan masyarakat sekitar melalui program CSR. Namun, melalui pelibatan masyarakat dan berangkat dari masalah di lingkungan sekitar maka CSR ini berjalan dengan baik.

Terdapat peningkatan kesejahteraan masyarakat yang terlibat dalam program CSR ini. Hal ini menjadi bukti bahwa terjadi trickle down effect dari program CSR yang dilaksanakan. Terlihat dari tingginya aktivitas kelompok binaan dan semakin meningkatnya kesejahteraan mereka.

Kondisi tersebut tentu saja menjadi bukti bahwa program CSR yang dijalankan secara partisipatif akan memiliki probabilitas keberhasilan yang lebih tinggi. Selain itu, hasil CSR ini memberikan sanggahan pada hasil kajian bahwa kebanyakan program CSR kurang berjalan efektif. 


\section{SIMPULAN}

Berdasarkan perhitungan Indeks Kepuasan Masyarakat (IKM), secara keseluruhan kepuasan masyarakat terhadap pelayanan program CSR Badak LNG menunjukkan parameter sangat baik. Tingkat kesesuaian antara kepuasan kinerja dengan tingkat kepentingan masyarakat diperoleh sebesar 94\% dan masuk dalam kategori sangat baik yang artinya secara keseluruhan kepentingan dan harapan masyarakat sudah sangat terpenuhi. Indikator kejelasan petugas pendamping, tanggung jawab petugas pendamping, kemampuan petugas pendamping, kesopanan petugas pendamping dan kepastian biaya pelayanan adalah indikator yang memiliki harapan tinggi dari masyarakat penerima manfaat, dan perusahaan memiliki kinerja yang sangat baik dalam hal tersebut.

Dampak positif yang diterima dari kegiatan CSR pada dimensi nature, wellbeing, economy, social di Kota Bontang sangat tinggi. diantaranya terjadinya peningkatan kualitas lingkungan, pemanfaatan potensi alam, peningkatan pendapatan masyarakat, pengentasan kemiskinan, peningkatan kemandirian UMKM, tereksposenya kebudayaan masyarakat, dan tingginya tingkat kepuasan masyarakat terhadap kegiatankegiatan CSR Badak LNG.

\section{DAFTAR PUSTAKA}

Asy'ari, Hasan. (2009). Implementasi Corporate Social Responsibility (CSR) sebagai Modal Social pada PT Newmont. Tesis Magister Ilmu Hukum Program Pasca Sarjana Universitas Diponegoro Semarang.

Badak LNG. 2016. Laporan Program Community Development 2016. Bontang: Badak LNG.

Badak LNG. Laporan Evaluasi Program CSR Badak LNG 2015-2016. Bontang: Badak LNG

Budimanta Arif, Rudito Bambang, Prestyo Adi. 2004. Corporate Social Responsibility: Jawaban Bagi Model Pembangunan Indonesia Masa Kini. Jakarta: Penerbit ICSD.

Cahyadi, Eddy; Yudistyana, Reta. 2016. Implementasi Community Development Bidang Pendidikan dalam Meningkatkan Kualitas SDM dan Mengatasi Kemiskinan.
Economics Development Analysis Journal, [S.1.], v. 5, n. 2, p. 289-303, june 2017. ISSN 25022725.Availableat: $<$ https://journal.unnes.ac.id / sju/index.php/edaj/article/view/14915>. Date accessed: 22 March 2017. doi: http://dx.doi.org/10.15294/edaj.v5i2.14915.

Jalal. 2010. Masukan bagi Program PROPER Kementrian Lingkungan Hidup. Jakarta: Laboratorium Sosiologi Universitas Indonesia.

Jha, Anand \& James Cox. 2015. Corporate social responsibility and social capitalAuthor links open overlay panel. Journal of Banking \& Finance, Volume 60, November 2015, Pages 252-270.

Hermansyah, Hermansyah; Sunaryo, Busori. 2016. Supervising Model of Independent Enterprise Group (Study of Community Development PT Badak NGL ). JEJAK: Jurnal Ekonomi dan Kebijakan, [S.1.], v. 9, n. 1, p. 1-15, Jun. 2016. ISSN 2460-5123. Available at: <https://journal.unnes.ac.id

/nju/index.php/jejak/article/view/7183/523 0>. Date accessed: 22 Feb. 2017. doi:http://dx.doi.org/10.15294/jejak.v9i1.71 83.

Kadlubek, Marta. 2015. The Essence of Corporate Social Responsibility and the Performance of Selected Company. Social and Behavioral Sciences, Volume 213, Pages 509-515

Lee, Min-Dong Paul. 2008. A Review of the Theories of Corporate Social Responsibility: Its Evolutionary Path and the Road Ahead. International Journal of Management Reviews Doi : 10.1111/j.1468-2370.2007.00226.xx, 2008.

Nurbaety, Annisa, Rina Ratnasih dan Hikmat Ramdan. 2015. Analisis Implementasi Corporate Social Responsibility PT. Bio Farma di Desa Sukamulya Kabupaten Sukabumi. Jurnal Sosioteknologi Volume 14, Nomor 2, Agustus 2015.

Rosyida, Isma dan Fredian Tonny Nasdian. 2011. Partisipasi Masyarakat dan Stakeholder dalam Penyelenggaraan Program Cororate Social Responsibility (CSR) dan Dampaknya terhadap Komunitas Perdesaan. Sodality: Jurnal Transdisiplin Sosiologi, Komunikasi dan Ekologi Manusia, April 2011, hlm. 51-70.

Saputro, Nurantono Setyo. 2010. Dampak Kegiatan Corporate Sosial Responsibility (CSR) PT. Telkom terhadap Kemampuan Masyarakat dalam Mengakses Sumber Daya di Kawasan 
Hanes Utama \& Busori Sunaryo/ Economics Development Analysis Journal 6 (3) (2017)

Punclut Bandung. Jurnal Perencanaan Wilayah dan Kota, Vol. 21 No. 2, Agustus 2010, hlm. 129 - 146 .

Sumodiningrat, Gunawan. 1997. Pembangunan Daerah dan Pemberdayaan Masyarakat. Jakarta: PT Bina Rena Pariwara

Wibisono, Yusuf. 2007. Membedah Konsep dan Aplikasi CSR (Corporate Social Responsibility). Gresik: Fascho Publishing. 